\title{
THE EXPERIENCES OF PREGNANT WOMEN WHO REQUEST AN ABORTION
}

\section{Susan Humpel, Herman Strydom}

\section{INTRODUCTION}

Pregnancy is a complex part of being a woman - it encompasses sexuality, a relationship, confrontation with contraception, the realisation of being pregnant, decisions and consequences (McCulloch, 1996:25). Mogano (1999:10) and Zimmerman (1997:15) agree that the discovery of an unwanted pregnancy evokes a variety of feelings in the woman, which lead to emotional turmoil. Feelings that are experienced range from ambivalence, surprise, happiness about fertility, fear of foetal abnormality, fear of birth, joy over motherhood, anger, feelings of guilt, confusion and shame, to anxiety about the social, economic, educational and emotional consequences of the pregnancy.

An unwanted pregnancy is often welcomed after a few days of anxiety and insecurity (Mogano, 1999:10). However, an unwanted pregnancy can also bring about pain and impetuous decisionmaking. The woman with an unwanted pregnancy finds herself in a crisis and the solution is often accompanied with feelings of pain (Kaufman, 1997:5; Mojapelo-Batka, 2000:3). Occasionally teenagers become pregnant while they are still at school, and this affects the entire life of the girls in that it can destroy their dreams about the future (Mogano, 1999:8). Although an abortion is not a solution to the problem of an unwanted pregnancy, it is often regarded by some as the only way out (Le Roux \& Botha, 1997:170).

An unwanted pregnancy and the experiences that pregnant women who request an abortion have are discussed in this article on the basis of the results that are obtained from the empirical investigation. Adolescence as a development stage and teenage pregnancy is singled out because it is characterised by unique elements that do not form part of the experiences that the adult pregnant woman has.

\section{PROBLEM STATEMENT}

In the social sciences it is accepted that the normative family structure is the nuclear family in which the father and mother together care for their children, and the gender roles determine the allocation of work within the family. Other family structures are often seen that deviate from this norm. Yet conceptions concerning the family have gradually changed and single-parent families have increased. Unwanted pregnancies, abortion or alternative forms of care for children are studied by social scientists because they threaten the two most important cornerstones of society, namely economic wellbeing and family life (Howes \& Green, 1997:1, 5).

The legal termination of pregnancy has been a reality in South Africa since 1997. The reproductive rights of women are acknowledged, which implies that women can have pregnancies terminated safely and confidentially on request (SA, 1996:1304). Although abortion is legal, safe and accessible to all women in South Africa, it is still the woman's decision and it is accompanied by mixed and contradictory feelings such as isolation, relief, pain and rage (Rulashe, 1999:23-24).

Women often experience the social, psychological and family tensions that accompany an unwanted pregnancy and this is seen as a crisis (Forrest, 1994:4; Kaufman, 1997:5). The decision-making process for the woman with an unwanted pregnancy is emotionally painful 
and confusing, because it entails dealing with conflicting feelings, values and convictions. The decision concerning an abortion is associated with other social and emotional problems in a woman's life and it is therefore seen as an immediate reaction to this crisis (Gameau, 1993:183; Reproductive Health Alliance Barometer, 2000:42; Zimmerman, 1997:15). The woman with an unwanted pregnancy is emotionally unsettled and she desperately needs counselling. Adolescents are especially vulnerable, because they feel that they often cannot discuss their unwanted pregnancy with their parents (Evangelisti, 2000:3, 5).

Pregnant women wish to be understood and supported in such crises in which they are often left to fend for themselves. They need opportunities to consider alternatives after having received sufficient information through objective counselling in order to make a responsible decision (Taylor, 1997:vi, 84). For pre-abortion counselling to be successful requires that the counsellor have knowledge and understanding of the world that a pregnant woman who requests an abortion lives in (McCulloch, 1996:87-89).

\section{AIMS AND OBJECTIVES}

This article discusses an unwanted pregnancy as well as the experiences of pregnant women who request termination of pregnancy. The objectives are as follows:

- To discuss an unwanted pregnancy as a life experience;

- To briefly distinguish between the experiences the teenage pregnant girl has in this particular development stage, and that of the adult pregnant woman who requests an abortion;

- To study the meaning the pregnant woman who requests termination of pregnancy attaches to the termination.

- To compile a profile of the pregnant woman who requests an abortion.

\section{RESEARCH METHODOLOGY}

\section{Design}

The survey procedure was used to obtain qualitative as well as quantitative data. The purpose of the survey procedure is to obtain information and facts pertaining to a phenomenon from people who are familiar with that particular phenomenon (De Vos, Strydom, Fouché \& Delport, 2002:172). A quantitative investigation focuses on variables and the data are processed statistically with a view to reliability (Creswell, 2003:18; Strydom, 1999:74). This investigation is also qualitative in nature as an intrinsic meaning of human experience is investigated (Ruben \& Babbie, 1997:310). The single system design was used, which studies the subject on a repetitive basis (Bloom, Fischer \& Orme, 1999:321-357; De Vos et al., 2002:151; Strydom, 1999:90).

\section{Respondents}

A pilot study was launched with 25 pregnant women who requested termination of pregnancy and participated in pre-abortion counselling at Potchefstroom Hospital. The only limitation that was placed on the respondents was a maximum gestation period of twelve weeks. The preinvestigation lasted from January 2003 to March 2003.

According to Creswell (2003:156), the population of the investigation must be clearly identified and an indication needs to be given of how the respondents were selected. The main investigation was launched directly after the pre-investigation. A sample was not used. The 
main investigation had two stages: the first part was based on patient indexes, and this was followed by a questionnaire.

\section{Patient indexes}

All the respondents were pregnant women who were referred to Potchefstroom Hospital after a request for abortion, regardless of the period of gestation and whether or not they engaged in pre-abortion counselling. Following a medical check-up at Gynaecology, Potchefstroom Hospital, the patients were referred to the social worker (investigator) with pre-abortion counselling in mind. A standardised form (patient index) with personal information was completed for all participants. For purposes of this study, data of one calendar year were used, in other words from 1 January to 31 December 2003. Two hundred and eighty (280) patient indexes were filled in and, by means of this data, a profile was compiled of pregnant women who requested abortion. These data were solely used for compiling a profile of the pregnant woman who requests an abortion.

\section{Questionnaire}

The respondents were those pregnant women who requested an abortion and were therefore referred to Potchefstroom Hospital. Following this, they underwent a medical check-up at Gynaecology, Potchefstroom Hospital. They had then been referred to the social worker (investigator) for pre-abortion counselling, but had not yet reached a gestation period of 12 weeks nor had they been for pre-abortion counselling. After ten months 150 pregnant women who had requested termination of pregnancy were involved in the main investigation, in other words from the beginning of April 2003 to the end of January 2004. Pre-abortion counselling was conducted in the office of the investigator and a peaceful atmosphere was deliberately created for the benefit of the respondents (Neuman, 2000:381).

The self-designed questionnaire was available in both Afrikaans and English in order to accommodate all respondents. A volunteer interpreter was used in cases where the participant understood only one another language. The questionnaires were filled in by the pregnant women themselves. If they were not capable of doing so, the questionnaire was used as an interview schedule and filled in by the investigator during the interview (Strydom, 1999:117). The same group of respondents also filled in the Self-Perception Scale at the commencement of the pre-abortion counselling.

Data obtained from the questionnaire and Self-Perception Scale formed part of the data obtained from the patient indexes, although the periods with regard to the patient indexes did not correspond exactly with those of the questionnaire and Self-Perception Scale. For the purposes of this article data from patient indexes, the Self-Perception Scale and the questionnaire were used at the beginning of pre-abortion counselling.

\section{Measuring instruments}

Quantitative data were collected based on a standardised format (patient index) with personal information regarding all pregnant women who requested an abortion. These data were computer processed by Statistical Consultation Services at the Potchefstroom Campus of the North-West University.

The qualitative data were collected at the beginning of pre-abortion counselling by means of indepth questionnaires (Taylor, 1997:5). The questionnaire, consisting of open-ended and closed questions, was based on the existing pre-abortion counselling programme (Royse, 2004:186, 188; Strydom, 1999:116). Data obtained from the closed questions were computer processed by 
Statistical Consultation Services at the Potchefstroom Campus of the North-West University, while data that were obtained from the open-ended questions were categorised and hand processed by the investigator.

The standardised Self-Perception Scale (SPS2), as supplied by Perspective Training, was also filled out at the beginning of pre-abortion counselling. This scale measures aspects such as selfimage, internal security and self-esteem. Data obtained were computer processed according to a computer program that was supplied by Perspective Training. With regard to the reliability of this scale, it was found that the Cronbach Alfa coefficient of insecurity was 0.74 , that of feelings of guilt 0.78 and that of worthlessness 0.80 (SAS Institute, 1999). Therefore this scale was reliable.

\section{Ethical aspects}

The human being is the subject of study in the social sciences and similar studies, which raises unique ethical issues that need attention (De Vos et al., 2002:62; Neuman, 2000:90-91; Strydom, 1999:18). Priority is given to the vulnerability of the women with unwanted pregnancies and to the manner in which they need to be treated so that they will benefit from it and to prevent any misleading expectations or confusion. This also ensured that the investigator would obtain a reliable account (Babbie, 2004:64-66; Creswell, 2003:64-65; De Vos et al., 2002:65).

The following ethical aspects received attention in this investigation:

- Permission to undertake the investigation was obtained from the Ethics Committee, Potchefstroom Hospital, and the departmental research committee, Health Department, North-West Province;

- The questionnaire was compiled in Afrikaans and English and tested for equivalence to ensure the correctness of the translation;

- This study does not necessitate a high educational level from respondents, and the same questionnaire was used as an interview schedule where the respondent was illiterate or experienced problems with the language;

- The questionnaire was filled in anonymously and it formed an integral part of pre-abortion counselling. The investigator herself was responsible for filling in the questionnaires during individual interview sessions that formed part of pre-abortion counselling. Information was therefore obtained directly from the respondent;

- Interviews were arranged in advance and were conducted in the privacy of an office in order to ensure confidentiality;

- Every respondent was called upon to give her voluntary cooperation following the explanation of the aim of the investigation. The ethical implications of the results are discussed thoroughly with the respondents as an ethical matter, namely that the results will be applied to the benefit of other women in the same situation and that the quality of social work service delivery with regard to pre-abortion counselling can be improved by it.

\section{DEFINITION OF CONCEPTS}

Unwanted /unplanned/unexpected pregnancy is a general and important consequence of forced, unplanned sexual intercourse and the inadequate use of contraception (Mogano, 1999:5; Rulashe, 1999:5). 
Contraception is defined as the act or practice of preventing sex from resulting in the woman becoming pregnant (Mogano, 1999:5).

Anonymity means that the information on the identity of a person cannot be linked to individual responses (Dondashe, 2001:31).

Confidentiality refers to the fact that no information that a person communicates to the investigator may be made public without the permission of that person, because the information is of a personal nature and must be regarded as such (Dondashe, 2001:31).

Privacy refers to a position where a person's thoughts or actions can occur without anyone's intrusion, so that the possibility that the individual's behaviour or thoughts can later be used to the embarrassment of the person involved is excluded (Dondashe, 2001:31).

Choice means that more than one course of action is open to you. You need to make a deliberate choice (Zimmerman, 1997:9).

Freedom of choice refers to the fact that no one can force the pregnant woman to continue the pregnancy or to undergo an abortion (Zimmerman, 1997:9).

\section{THE EXPERIENCES OF PREGNANT WOMEN WHO REQUEST AN ABORTION}

\section{Feelings during an unwanted pregnancy}

Women experience an unwanted pregnancy in different ways and the following are some of the feelings experienced by them, according to literature.

- Ambivalence - Weighing different options, resistance from the biological father and reactions of the family can evoke ambivalence in the pregnant woman and influence her perception of the situation (Henwick, 2001:19).

- Anxiety and emotional shock - The adolescent experiences anxiety when she becomes aware of the unwanted pregnancy and does not always have the capacity to reach out for assistance because of her emotional blockage (Evangelisti, 2000:17). This is sometimes also true of adult women.

- Problems of thinking clearly - An unwanted pregnancy influences the woman's ability to think clearly, to concentrate and to make decisions. Accurate decisions and objective reasoning are exceptionally difficult (Parry, 1990:21).

- Avoidance and preoccupation - The pregnant woman is overwhelmed by the situation, displays limited insight and avoids thinking about it in any way whatsoever (Reisser \& Reisser, 1992:4).

- Denial - The woman with an unwanted pregnancy denies the reality and consequently withdraws (Reisser \& Reisser, 1992:4). This protects her against the cause of her pain. To the adolescent, it seems impossible that she could be pregnant and denial is an immediate way out for her (Evangelisti, 2000:17).

- Anger - The unwanted pregnancy evokes anger and frustration in the woman (Kaufman, 1997:126). She is cross with herself, her parents, God, the biological father and everyone else, and develops anger in an attempt to justify and sanction her decision to have an abortion (Van der Berg, 1997:73).

- Depression - Hopelessness causes depression in the pregnant woman who requests an abortion (Evangelisti, 2000:17). 
- Fear - The pregnant woman fears a negative reaction from, and being rejected by, the biological father and other significant people (Rulashe, 1999:27; Van der Berg, 1997:73).

- Feelings of guilt - Those who contemplate an abortion consider it unacceptable and wrong, and experience feelings of guilt and shame (Evangelisti, 2000:17; Kaufman, 1997:126; Van der Berg, 1997:73).

- Helplessness - The woman with an unwanted pregnancy is vulnerable and impressionable. She feels powerless because she experiences that she is incapable of handling the situation (McCulloch, 1996:84; Van der Berg, 1997:74).

- Worthlessness - The woman experiences herself to be a failure because of the unwanted pregnancy (Van der Berg, 1997:73).

- Detachment - In a state of detachment, a pregnant woman can make an ill-judged decision on abortion by distancing herself from the reality of the pregnancy and the baby (Evangelisti, 2000:17).

By means of the Self-Perception Scale, the inner insecurity, feelings of guilt and lack of selfesteem of the 150 pregnant women who requested termination of pregnancy and took part in pre-abortion counselling were measured; the results are indicated in Table 1.

TABLE 1

INNER INSECURITY, FEELINGS OF GUILT AND LACK OF SELF-ESTEEM

\begin{tabular}{|l|l|}
\hline $\begin{array}{l}\text { Inner insecurity } \\
\text { (Score = 44) }\end{array}$ & $\begin{array}{l}\text { The respondents experience insecurity and then panic easily. They feel } \\
\text { that they are rejected and are then afraid of hurting emotionally. They } \\
\text { feel unsafe within their circumstances and then fear the future. They } \\
\text { experience a lack of security and feel threatened by their present } \\
\text { circumstances. }\end{array}$ \\
\hline $\begin{array}{l}\text { Feelings of guilt } \\
\text { (Score = 37) }\end{array}$ & $\begin{array}{l}\text { The respondents feel guilty and then admit guilt to everything that } \\
\text { goes wrong. They feel that they deserve punishment and condemn } \\
\text { themselves. They live with self-regret. They feel that everything is } \\
\text { always their fault, and feelings of guilt dominate their lives. }\end{array}$ \\
\hline $\begin{array}{l}\text { Lack of self-esteem } \\
\text { (Score = 30) }\end{array}$ & $\begin{array}{l}\text { The respondents feel unimportant and worthless. They think that } \\
\text { people think badly of them and do not respect them. They do not feel } \\
\text { special or that they do mean anything to others. }\end{array}$ \\
\hline
\end{tabular}

GRAPH 1

SELF-PERCEPTION

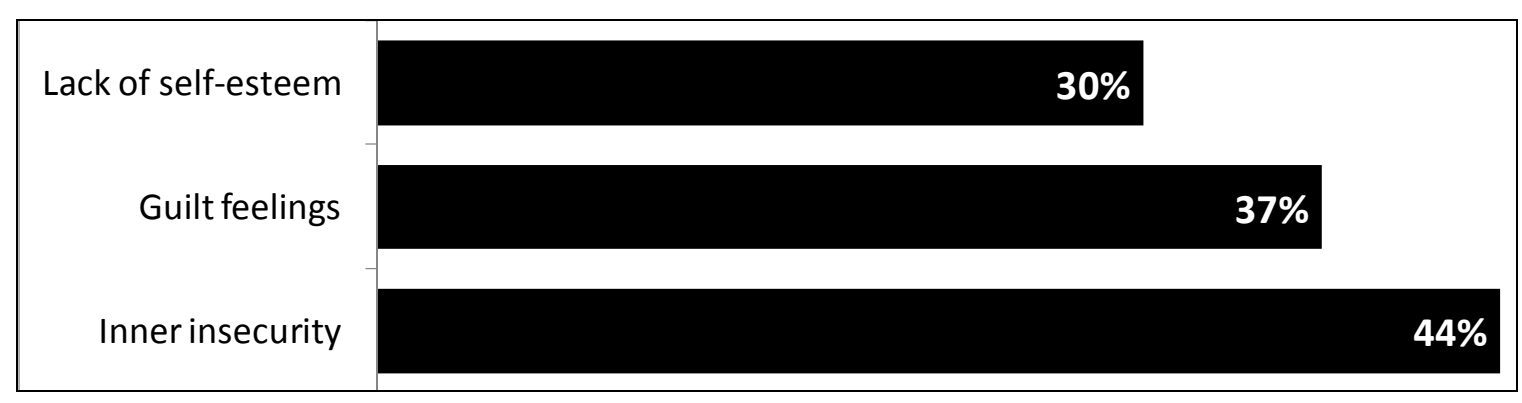

Graph 1 indicates a score of $30 \%$ for a lack of self-esteem, 37\% for feelings of guilt and $44 \%$ for inner insecurity. This implies that more than $25 \%$ indicated a need for improvement (Self- 
Perception Scale (SPS2), 2004:6). This corresponds with the findings of Evangelisti (2000:17) and Van der Berg (1997:73), namely that women who consider an abortion have low selfesteem before the pregnancy in most cases, that it increases during the unwanted pregnancy and that it is then accompanied by intense emotions. Furthermore, she is confused, cannot concentrate and feelings of worthlessness are so overwhelming that she can no longer think rationally.

\section{Causes of an unwanted pregnancy}

An unwanted pregnancy is accompanied by passion, seeing that sexual deeds are not always planned (Taylor, 1997:31). Pregnancy relates directly refers to contraception, namely no contraception during conception, or that it was not used correctly, or that the method of contraception failed (Mogano, 1999:2). Young adults and teenagers sometimes consider the enjoyment of sexual pleasure as their right without considering the effects. However, they are not mature enough to take the consequences of their behaviour into consideration in time (Rulashe, 1999:89). Some adult women are uninformed about contraception. Others do not think about it in time or are dissatisfied with the effect of different means of and/or devices for contraception and discontinue using them immediately (Taylor, 1997:31).

Women deny their irresponsibility with regard to using contraception and are not entirely honest about using it shortly before the pregnancy (Mogano, 1999:21). An unwanted pregnancy is often planned in the hope that a personal problem can be solved by it. Therefore the pregnancy is a way in which the woman can manipulate her environment, although she does not necessarily want the baby, as in the case where a possibility exists that a specific relationship or marriage is about to be terminated. An abortion is then seen as a way out, should the pregnancy not yield the desired results (Le Roux \& Botha, 1997:170).

Some women undergo repeated abortions in spite of the availability of contraception. It is not always the unfit, inferior woman with a low intellectual ability who requests abortion more often than once. They are women who use contraception irregularly, have a history of psychic shortcomings, maintain unstable relationships and display indifference towards contraception (Le Roux, 1995:144).

\section{Confirmation of the unwanted pregnancy and reaction to it}

According to Kaufman (1997:160), the most difficult aspect of an unwelcome pregnancy is the period of waiting, namely the period of waiting after a woman has had unsafe sex until the pregnancy is confirmed. Skipping the menstrual period with the associated sensitivity of breasts, dizziness and nausea as a result of the change of reproductive and digestive hormones that normally appear from the second to eighth week of pregnancy are the first signs of pregnancy. Tiredness, listlessness, and sleep and emotional disturbances are frustrating symptoms of early pregnancy that induce her to undergo a pregnancy test. One should display an understanding of her fear of having a pregnancy test done, or tardiness to do so, as a defence mechanism to escape reality.

The immediate reactions of women with unwanted pregnancies are secrecy and shock, because they find it difficult to acknowledge, seeing that "unwanted pregnancies involve exposing the contradictions within these women's lives, which may be difficult to face" (McCulloch, 1996:32). Their entire world has suddenly changed, and they withdraw because of the emotional pain associated with it (Zimmerman, 1997:19). At the confirmation of an unwanted pregnancy, most women seem to be preoccupied with the problem, lack concentration, become forgetful, become unproductive and finally withdraw socially. Women deny the pregnancy and 
often delay making a decision in this regard until the physical signs appear (McCulloch, 1996:32). The woman's social circumstances and the meaning that she attaches to the pregnancy play a role in her reaction to the pregnancy. She has a multitude of questions, such as how it could have happened to her, what the biological father will have to say about it, what her parents will have to say, and what she should do. Regardless of how soon the pregnant woman decides on possible options, she is pregnant for a period and undergoes physical changes that are associated with pregnancy (Kaufman, 1997:124; Rulashe, 1999:9).

\section{The woman with the unwanted pregnancy}

In accordance with Munichen's systems theory, a human is a complex being comprised of social, moral, physical and cognitive systems that mutually influence one another (Britz, 1997:4-5). The physical, socio-cultural and psychological environments can influence and mould people. Systems have divergent and different rules, and if they are not adhered to, it can lead to emotional and relationship problems (Britz, 1997:5). Every woman with an unwanted pregnancy experiences unique circumstances and personal opinions on the experience that determine how she will handle it (Gamaeu, 1993:184). It is essential to understand the woman who does not see her way clear to go through with a pregnancy and have a child. Factors such as finances, accommodation, physical health, mental health and need for attention can drive her to a breaking point, which leads her to see the option of abortion as the only way out (Mogano, 1999:18-20). A few important aspects are relevant here.

- Needs of the woman with an unwanted pregnancy - An unwanted pregnancy and abortion is an issue and a difficult subject to discuss with someone. Besides, secrecy is important to the pregnant woman. It is not necessarily a weakness. It can be an indication that she takes sole responsibility for her crisis and wants to handle it on her own (Rulashe, 1999:37). An unwanted pregnancy evokes many questions on spiritual and other aspects, but the risk of sharing this with someone can lead to the situation that the pregnant woman prefers to experience the crisis on her own (Kaufman, 1997:133). Simultaneously, she experiences an intense need to share her problem with someone and to be understood and supported (Taylor, 1997:79). She desires understanding, love and support from the biological father, friends and parents (Henwick, 2001:16).

The woman with an unwanted pregnancy wants to obtain information on all the options and associated risks in order to be able to make a responsible decision. She wants to form her own opinion on her circumstances, such as exploring the ambivalence concerning the decisionmaking process, values and convictions (McCulloch, 1996:85; Taylor, 1997:86). In this crisis she also experiences a need for approval of her actions. The emotional crisis in which the pregnant woman finds herself influences her ability to absorb information on her crisis (PolkWalker, 1993:22). The woman with an unwanted pregnancy can even have a need to abort all on her own in a desperate attempt to rid her of the pregnancy (Kaufman, 1997:134).

The woman with strong beliefs who has become pregnant has a need for confession, admission of guilt and forgiveness. The path to recovery is painful and demands support and trust (Fourie, 2004a:11; Fourie, 2004b:11; Taylor, 1997:44). She desires open arms, wisdom and understanding of her wounds from other women and wants to be accepted unconditionally on spiritual grounds (Reisser \& Reisser, 1992:3).

- The woman's ambitions - The average woman creates all possible opportunities for her family. The presence of still another child can be experienced as a threat to upholding the standard of living and satisfying her ambitions. Pregnancy is therefore unwanted if the 
pregnant woman's sense of responsibility with regard to herself and her current family is threatened (Rulashe, 1999:94).

- The relationship with the biological father - An unwanted pregnancy has a unique influence on every relationship because of the biological father's personal circumstances and his reaction to the pregnancy (Taylor, 1997:20). The dilemma in which the woman finds herself influences her relationship with the biological father. The relationship can even end negatively, because the biological father does not realize his responsibility with regard to the unwanted pregnancy and to provide emotional support (Rulashe, 1999:93; Taylor, 1997:59).

- The attitude of the biological father - Confirmation of a pregnancy can be a shock to the biological father and can evoke feelings of fear, disbelief, confusion, unprecedented calm, excitement and despair. His feelings are often not taken into consideration, but his attitude determines the manner in which the woman handles her pregnancy. Men can disappear, give limited financial support or assume an apathetic attitude because of anger, feelings of guilt and powerlessness (Taylor, 1997:21). He can deny his responsibility, withdraw from it and leave the woman to handle the reality on her own (McCulloch, 1996:26). Not being involved in a co-habitation relationship can be very strenuous. Sometimes women are rejected by the biological father once it has become known that she is pregnant, and she then loses his emotional support, which leads to a sense of loss and unleashes emotional stress (Rulashe, 1999:93). A supportive biological father can influence the unwanted pregnancy positively (McCulloch, 1996:26).

- Poverty - Housing, food and clothing are people's most basic needs. There are people who have to go without these things and another child can mean that limited resources need to be divided more carefully among the individual members of the family. Uncertainty about the financial position increases tension in the women if she becomes pregnant when she is not prepared for it. According to Henwick (2001:19), studies indicate that the woman with a low socio-economic status runs a greater risk of becoming depressed during her pregnancy.

- Social factors - If a woman lives in poverty, a pregnancy can contribute to the fact that she has no goal to live for. Factors such as unemployment, a low-salary occupation, absence of the biological father and marital status can determine whether a pregnancy is undesirable (Rulashe, 1999:29-30).

\section{Decision-making process}

Making a decision on the unwanted pregnancy starts when a woman realises that she is pregnant. This decision-making process takes on a variety of forms and varies between the immediate realization of the pregnancy and a long period of denial before she becomes aware of the physical symptoms (Evangelisti, 2000:19). Decision-making is complex by nature. It is based on religious, economic, social, cultural and medical considerations and is accompanied by psychological tension that manifests in cognitive and affective symptoms such as ambivalence, confusion, depression, guilt and anger (Mojapelo-Batka, 2000:31; Polk-Walker, 1993:22). The literature indicates that such a decision is often made on the spur of the moment, while the pregnant woman is confused, and seldom takes the needs of the biological father and next of kin into consideration.

Although the pregnant woman is not forced to take a hasty decision, urgency is nevertheless linked to a decision if she considers abortion as an option, because she needs to take into consideration the time limit of twelve weeks gestation. It is also physically, socially, medically 
and psychologically better for a pregnant woman to make a decision about the unwanted pregnancy as soon as possible (SA, 1996:1302; Taylor, 1997:21, 22). In this way, the pregnant woman experiences that an abortion is actually the only choice in her specific circumstances (Mojapelo-Batka, 2000:66). The pressure that is exerted by the biological father or parents to abort because the unwanted pregnancy is an embarrassment and unwanted is also a reality. However, freedom of choice is an non-negotiable right (Reisser \& Reisser, 1992:5).

The decision to proceed with the pregnancy or to terminate it is difficult and affects several aspects of the woman's life. Some women know instinctively what they are going to do, but others are confused (Kaufman, 1997:125). The support of a confidant is important for mutual decision-making (Rulashe, 1999:37). This decision has long lasting effects, namely: "What you believe will influence what you decide. It's not easy to do what is unpleasant for the sake of what you believe, but what you do now will become your personal statement about the value of human life" (Zimmerman, 1997:27). A balanced decision can, however, take a period of a few weeks to finalise (Taylor, 1997:21).

\section{Reasons for requesting abortion}

According to the literature, there are a few reasons for a voluntary abortion - in other words, an abortion during the period before the gestation of twelve weeks has elapsed.

- Socio-economic reasons - These include unemployment, fear of losing a job, hope of obtaining a job and loss of income during pregnancy (Reproductive Health Alliance Barometer, 1997:17). Women who suffer financially rather decide on abortion than suffering financially in order to raise a child. The absence or lack of involvement of the biological father causes an additional financial burden. Young women with parents in highincome groups, educational qualifications and occupational status are inclined to have a pregnancy terminated because of their own ambitions and to exercise their reproductive rights (Rulashe, 1999:76; Sekudu, 2001:191).

- Insufficient emotional support - The pregnant woman is left alone to take responsibility for the child all on her own, and abortion is then a way out (Reproductive Health Alliance Barometer, 1997:17; Rulashe, 1999:76).

- Single-parenthood - Motherhood implies the preparedness to care for a child for a period of 18 years and this demands patience, maturity and energy. Women sometimes feel that they are not ready for this emotionally and therefore request an abortion. The unmarried woman with loss of financial support and with feelings of guilt and tensions about destroyed dreams of the future experiences the unwanted pregnancy as traumatic (Rulashe, 1999:80). Women with ambition with regard to their careers and future exercise their reproductive rights more readily and decide on abortion (McCulloch, 1996:35; Sekudu, 2001:191).

- Extramarital relationships - Fear of being confronted by reality as well as by her husband's and her next of kin's reaction to her mean that an abortion is the way out for a pregnant woman under these circumstances (Reproductive Health Alliance Barometer, 1997:17; Rulashe, 1999:78).

- Successive pregnancies - An unplanned pregnancy, when a married couple already have the planned number of children, is sometimes given as reason for an abortion. Women do not see their way clear to have the additional burden of another child that was not planned for (Rulashe, 1999:78). 
According to data obtained from the 150 questionnaires, the reasons for abortion during this investigation were indicated as in Table 2.

TABLE 2

REASONS FOR THE TERMINATION OF PREGNANCY

\begin{tabular}{|c|c|c|c|c|c|c|c|c|}
\hline & 异 & 胥焉 & 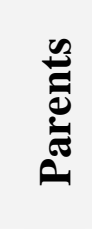 & 节 & $\frac{\vec{Z}}{\frac{\vec{E}}{0}}$ & 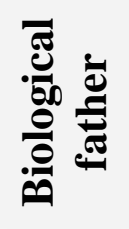 & 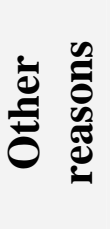 & 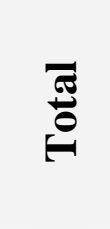 \\
\hline $\begin{array}{l}\mathrm{N}=150 \\
\text { Shortfall = } 78\end{array}$ & 10 & 10 & 6 & 10 & 18 & 12 & 6 & 150 \\
\hline $100 \%$ & 13.89 & 13.89 & 8.33 & 13.89 & 25 & 16.67 & 8.33 & $100 \%$ \\
\hline
\end{tabular}

The majority of pregnant women who had requested an abortion, namely 18 (25\%), gave the fact of not being ready to proceed with the pregnancy and having a baby as their reason. The biological father was a further reason for an abortion request by 12 (16.67\%) respondents, while finances and the fact that the pregnant woman already has children were each given as reasons by $10(13.89 \%)$.

\section{THE PROFILE OF PREGNANT WOMEN WHO REQUEST ABORTION}

In order to compile an accurate profile of the pregnant woman who requests abortion, two methods were used in this investigation to obtain the necessary data.

- Patient indexes - All the respondents in this group were pregnant women who had requested an abortion and who had been referred to Potchefstroom Hospital, regardless of the period of gestation. Following a medical check-up at Gynaecology, Potchefstroom Hospital, the patients were referred to the social worker (investigator). A standardised form (patient index) that provides personal information was filled in with regard to every pregnant woman who had requested an abortion there. For purposes of this study, data with regard to 280 patients of one calendar year were used - from 1 January to 31 December 2003.

- Questionnaire - All these respondents were pregnant women who had requested an abortion and who were referred to Potchefstroom Hospital. Following a medical check-up at Gynaecology, Potchefstroom Hospital, the patients were referred to the social worker (investigator) for pre-abortion counselling. This group of pregnant women had not yet reached a gestation period of 12 weeks and had not yet engaged in pre-abortion counselling. For the purposes of this study, data with regard to 150 pregnant women were used during a period of ten months - from the beginning of April 2003 to the end of January 2004.

Data obtained from the questionnaires form part of the patient indexes but contain more details, and specific questions were answered. The period during which the questionnaire was completed also differs from that of the patient indexes. 


\section{Identifying details}

TABLE 3

AGE DISTRIBUTION

\begin{tabular}{|l|c|c|c|c|c|c|c|c|c|c|c|c|c|c|c|}
\hline $\begin{array}{c}\text { Age in } \\
\text { years }\end{array}$ & $\mathbf{1 4}$ & $\mathbf{1 6}$ & $\mathbf{1 8}$ & $\mathbf{2 0}$ & $\mathbf{2 2}$ & $\mathbf{2 4}$ & $\mathbf{2 6}$ & $\mathbf{2 8}$ & $\mathbf{3 0}$ & $\mathbf{3 2}$ & $\mathbf{3 4}$ & $\mathbf{3 6}$ & $\mathbf{3 8}$ & $\mathbf{4 0}$ & $\mathbf{4 2 +}$ \\
\hline $\mathrm{N}=280$ & 2 & 10 & 27 & 46 & 46 & 41 & 17 & 23 & 22 & 15 & 12 & 7 & 7 & 2 & 3 \\
\hline $100 \%$ & 0.71 & 3.57 & 9.64 & 16.43 & 16.43 & 14.64 & 6.07 & 8.21 & 7.86 & 5.36 & 4.29 & 2.5 & 2.5 & 0.71 & 1.07 \\
\hline
\end{tabular}

Data from the patient indexes (Table 3) indicate that the majority of the pregnant women, namely 92 (32.86\%), who requested an abortion at Potchefstroom Hospital were between 20 and 22 years of age. The Self-Perception Scale indicates that $67 \%$ of pregnant women who requested an abortion were between 20 and 30 years of age. This corresponds with the details in Table 6, namely 195 (69.64\%).

\section{DIAGRAM 1 \\ CAREER STATUS}

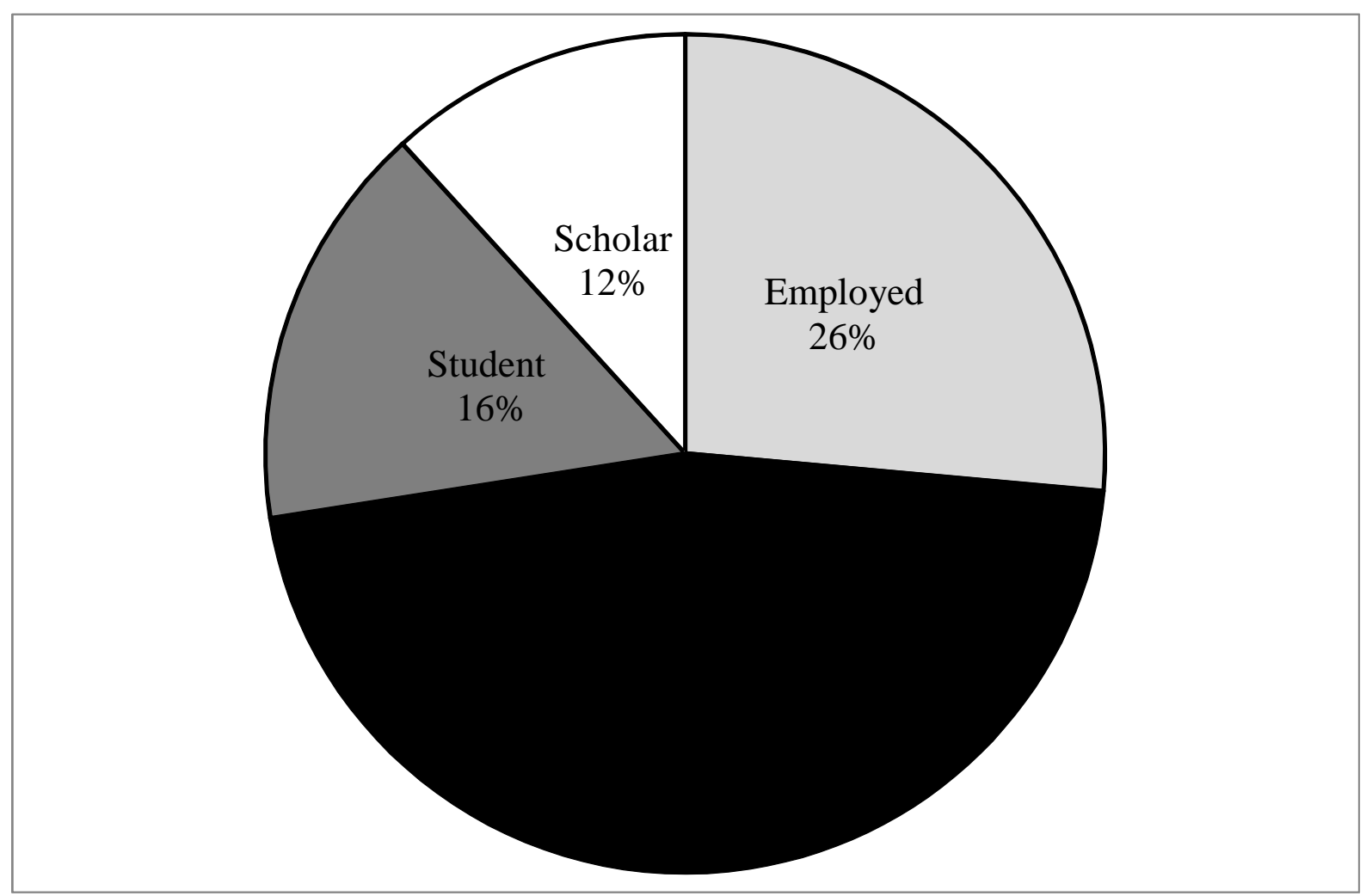

The diagram above gives a visual indication of the different relationships with regard to career status, as also indicated in the Table 4.

TABLE 4

CAREER STATUS

\begin{tabular}{|l|c|c|c|c|c|}
\hline Career status & Employed & Unemployed & Student & Scholar & Total \\
\hline $\mathrm{N}=280$ & 74 & 129 & 44 & 33 & 280 \\
\hline $100 \%$ & 26.43 & 46.10 & 15.71 & 11.76 & 100 \\
\hline
\end{tabular}


According to the patient indexes (Table 4), the number of unemployed pregnant women who requested an abortion are in the majority, namely 129 (46.10\%). Employed women numbered $74(26.43 \%)$, students $44(15.71 \%)$ and scholars $33(11.76 \%)$.

TABLE 5

NUMBER OF CHILDREN

\begin{tabular}{|l|c|c|c|c|}
\hline Number of children & Children & No children & Uncertain & Total \\
\hline $\mathrm{N}=280$ & 123 & 92 & 65 & 280 \\
\hline $100 \%$ & 43.93 & 32.86 & 23.21 & 100 \\
\hline
\end{tabular}

Data from patient indexes (Table 5) indicate that 123 (43.93\%) of the pregnant women who had requested an abortion already had children and that this was therefore not a first pregnancy that they wished to terminate. It was a first pregnancy only with regard to 92 (32.86\%) women. For $65(23.21 \%)$ women, it was uncertain whether the pregnant woman did indeed have other children.

TABLE 6

\section{MARITAL STATUS}

\begin{tabular}{|c|c|c|c|c|c|c|c|c|}
\hline 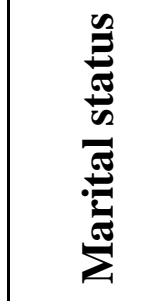 & 茪 & 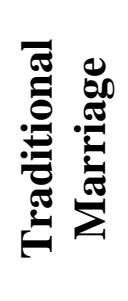 & 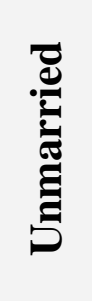 & 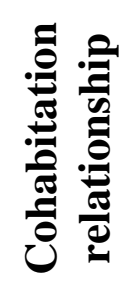 & 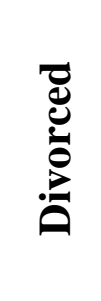 & ${ }_{3}^{0}$ & 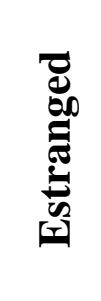 & $\stackrel{\bar{\sigma}}{\theta}$ \\
\hline $\mathrm{N}=150$ & 8 & 1 & 123 & 10 & 1 & 2 & 5 & 150 \\
\hline $100 \%$ & 5,33 & 0,67 & 82 & 6,67 & 0,67 & 1,33 & 3,33 & 100 \\
\hline
\end{tabular}

Table 6 indicates that $123(82 \%)$ of the pregnant women who had requested an abortion were unmarried; $10(6.67 \%)$ were in cohabitation relationships and $8(5.33 \%)$ were married women. These data were obtained from the questionnaires only.

\section{Period of gestation}

\section{TABLE 7}

PERIOD OF GESTATION

\begin{tabular}{|l|c|c|c|c|c|c|c|c|c|c|c|c|c|c|c|c|c|c|}
\hline Weeks & 4 & 5 & 6 & 7 & 8 & 9 & 10 & 11 & 12 & 13 & 14 & 15 & 16 & 17 & 18 & 19 & 20 & $21+$ \\
\hline $\begin{array}{l}\text { N=280 } \\
\text { Short- } \\
\text { fall=5 }\end{array}$ & 11 & 12 & 16 & 29 & 41 & 33 & 31 & 29 & 16 & 10 & 8 & 6 & 2 & 0 & 16 & 0 & 8 & 7 \\
\hline $100 \%$ & 4 & 4,36 & 5,82 & 10,55 & 14,91 & 12,00 & 11,27 & 10,55 & 5,82 & 3,64 & 2,91 & 2,18 & 0,73 & 0 & 5,82 & 0 & 2,91 & 2,55 \\
\hline
\end{tabular}

Data from the patient indexes (Table 7) indicate that the gestation period at which most pregnant women requested termination of pregnancy was 8,9 and 10 weeks respectively, 
82

namely 41 (14.91\%), $33(12.00 \%)$ and 31 (11.27\%). Fifteen (5.46\%) pregnant women had even requested an abortion at a gestation period of 20 weeks and longer.

\section{Period aware of pregnancy before the request for an abortion}

TABLE 8

PERIOD AWARE OF PREGNANCY

\begin{tabular}{|l|c|c|c|c|c|c|c|c|}
\hline Period & 1 day & 2 days & 3 days & 4 days & 5 days & 6 days & 7 days & Total \\
\hline $\mathrm{N}=150$ & 3 & 7 & 7 & 6 & 13 & 6 & 108 & 150 \\
\hline $100 \%$ & 2 & 4.67 & 4.67 & 4 & 8.67 & 4 & 72 & 100 \\
\hline
\end{tabular}

Data from the questionnaire (Table 8) indicate that the period that had elapsed since the woman had become aware of the pregnancy until she requested an abortion was seven days in most cases $108(72 \%)$. Only 3 (2\%) women requested an abortion on the same day or within one day.

\section{Announcement}

With regard to the 150 respondents who filled in the questionnaire:

- 137 (91.33\%) women had discussed the pregnancy with someone, while 13 (8.67\%) women had discussed it with nobody; and

- only $128(85.33 \%)$ women had discussed their request for abortion with someone, while 22 $(14.67 \%)$ preferred not to discuss it with someone at all.

\section{Contraception}

\section{TABLE 9}

METHODS OF CONTRACEPTION

\begin{tabular}{|c|c|c|c|c|c|c|c|c|c|c|c|c|c|c|c|}
\hline \multirow[t]{2}{*}{ 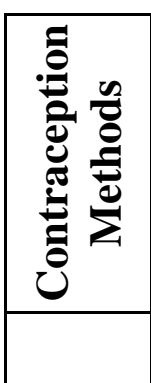 } & \multicolumn{2}{|c|}{ 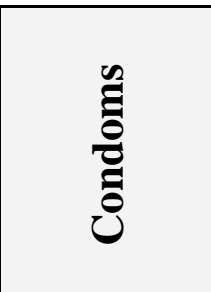 } & \multicolumn{2}{|c|}{ 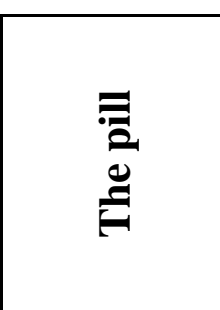 } & \multicolumn{2}{|c|}{ 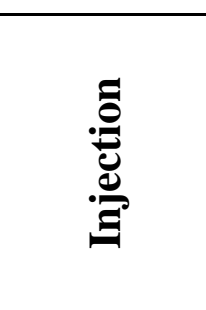 } & \multicolumn{2}{|c|}{ 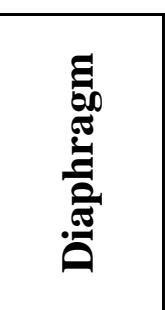 } & \multicolumn{2}{|c|}{ 己ِ } & \multicolumn{2}{|c|}{$\stackrel{\bar{\Xi}}{\bar{\Xi}}$} & \multicolumn{2}{|c|}{ 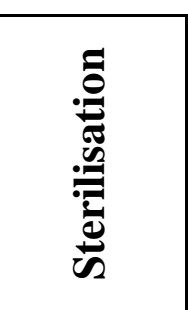 } & \multirow[t]{2}{*}{$\underset{\mathrm{O}}{\mathrm{O}}$} \\
\hline & Yes & No & Yes & No & Yes & No & Yes & No & Yes & No & Yes & No & Yes & No & \\
\hline $\mathrm{N}=150$ & 46 & 34 & 24 & 54 & 9 & 69 & 0 & 78 & 2 & 76 & 2 & 76 & 0 & 78 & 150 \\
\hline \multirow[t]{2}{*}{$100 \%$} & 57,50 & 42,50 & 30,77 & 69,23 & 11,54 & 88,46 & 0 & 100 & 2,56 & 97,44 & 2,56 & 97,44 & 0 & 100 & \multirow[t]{2}{*}{$100 \%$} \\
\hline & Short & fall $=7$ & & Shor & & & & & & & & & & & \\
\hline
\end{tabular}

Data from the 150 filled in questionnaires (Table 9) indicate that $79(52.67 \%)$ women maintain that they had used contraceptives and nevertheless became pregnant, while $71(47.33 \%)$ women had not used any contraceptives. The methods of contraception that were mostly used were the condom $-46(57.50 \%)$ and the pill $-24(33.77 \%)$. 


\section{Development stage}

With regard to the 149 pregnant women who filled in the questionnaire (one questionnaire was not filled in), the following results were obtained pertaining to whether or not the foetus is a living being:

- Women being uncertain as to whether the foetus is a living being - 77 (51.68\%);

- Women being convinced that the foetus is not a living being - 34 (22.82\%);

- Women being totally uncertain about it - 38 (25.50\%).

\section{Other relevant aspects}

From the 150 filled in questionnaires, the following relevant results were obtained with regard to the profile of the pregnant woman who requests an abortion:

- Seventy (70) (47.95\%) respondents believed that abortion is right, while $76(52.05 \%)$ respondents saw it as wrong. Four respondents did not answer this question;

- One hundred and fourteen (114) (78.08\%) respondents believed that their circumstances justify an abortion; $16(10.96 \%)$ were uncertain and 16 (10.96) were of the opinion that their circumstances did not justify it. Four respondents refrained from answering this question.

- One hundred and seven (107) (71.81\%) respondents had the expectation that an abortion would solve their problems; $20(13.42 \%)$ indicated that an abortion would not solve their problems and $22(14.77 \%)$ were uncertain about this. One participant refrained from answering the question.

\section{TEENAGE PREGNANCY}

\section{Adolescence as development stage}

Adolescence usually occurs between about 13 and 18 years of age. It is a period of important developmental tasks, self-image modification and of forming a new self-concept, the development of personal relationships and responsibilities, and preparation for adapting to the complexities of society.

The awakening sexuality of adolescents contributes to their feelings about their identity (Geldenhuys \& De Lange, 2001:92). They must learn to handle their sexual needs in a socially acceptable manner, so that this has a positive influence on the development of their identity. Heterosexual relationships normally commence during adolescence and their identity as sexual beings develops accordingly. Sexual intercourse is associated with growing up and marriage. Sexual behaviour refers to conformity of behaviour to that of the peer group and mutual expectations in a relationship. Adolescents often rebel, force their independence and wish to be different. Their cognitive abilities have not yet developed fully, and an adolescent is a risk of committing impulsive actions (Evangelisti, 2000:3). Because of the impact of the physical changes and circumstances of the teenager, this development stage in itself is seen to be a crisis period. They search for their own identity and fight for a place in society. Adolescence is characterised by pressure from parents and the peer group, and with changing roles, values and behaviour that need to be adapted (Evangelisti, 2000:3). The course of adolescence as a development stage influences the future of the adolescent as well as adult life (Le Roux \& Botha, 1997:170). 


\section{The experiences of pregnant teenagers}

Often the person who requests an abortion is an adolescent. On the one hand, the adolescent is confronted by the development crisis of adolescence and, on the other hand, by the circumstantial crisis of an unwanted pregnancy (Geldenhuys \& De Lange, 2001:92). Research has found that many teenagers who are sexually active are unaware of the risk of an unwanted pregnancy or are inclined to ignore the consequences of their behaviour. They display an apologetic attitude and deny the risks, because they do not realise the long-term consequences of their behaviour. The consequences of their decisions are not taken into account and they easily become involved in unsafe sex with the expectation that they will not fall pregnant (Evangelisti, 2000:3; Henwick, 2001:18; Mogano, 1999:9). Beside the fact that the adolescent is at greater risk of an unwanted pregnancy than the adult woman, she is also physically and socially not ready to start a family yet.

A pregnant teenager must be understood within the context of the specific world she lives in, namely the family and broader social environment. The socio-economic environment determines the context of the adolescent's psycho-social development, namely values and beliefs as well as attitude with regard to pregnancy, abortion, adoption and motherhood (Evangelisti, 2000:21). Teenagers are inclined to request an abortion in spite of the possibility that abortion is rejected in the specific culture which creates confusion and anxiety. The teenager's experience of teenage pregnancy is three-dimensional, namely physical, psychological and spiritual (Britz, 1997:51). The adolescent who requests an abortion finds herself in a unique educational and life situation. She is caught up in irrational beliefs and has to make a difficult decision in a time in which she herself is dependent on the guidance of adults (Britz, 1997:10, 51). The adolescent must have sound decision-making skills before she can decide on how to deal with the unwanted pregnancy.

\section{The adolescent's reasons for an abortion}

Although the reasons for an abortion are the same for adult women and teenagers, a few unique reasons are linked to the pregnant teenager.

- Adolescents fear their parents' reaction to an unwanted pregnancy - an unwanted pregnancy is an embarrassment because the teenager has deviated from the values of her parents and because of the community's rejection of pre-marital sex. It is untimely and encroaches upon the teenager's objectives, and an abortion is then the only way out, in her opinion. Teenagers do not share this with their parents out of fear of disappointment, anger and rejection, and then take everything on themselves in an attempt to spare their parents the heartache. Many teenagers have preconceived notions that parents will not understand or support them. The mere idea of informing them about the unwanted pregnancy is to them more stressful than the actual act of communicating the information. They deny themselves the phase of support and concern of their parents and lose sight of the possibility that the news can strengthen the relationship between the parents and the children, and then rather request an abortion (Kaufman, 1997:46; McCulloch, 1996:37; Reproductive Health Alliance Barometer, 1997:17; Taylor, 1990:43).

- The peer group does not easily influence the pregnant teenager during the decision-making process. However, if she knows someone who has undergone an abortion, it is relatively easy for her to make her decision (Evangelisti, 2000:25).

- Age and emotionally not ready - often adolescents mention concrete reasons for terminating a pregnancy. The fear of social rejection is linked to this (Evangelisti, 2000:25). 
- School career and studies - completing her school career and/or studies as well as fulfilling her plans for the future are her concrete arguments for terminating her pregnancy (Evangelisti, 2000:25).

- Silence and secrecy - Geldenhuys and De Lange (2001:96) emphasise silence and secrecy as concrete reasons why adolescents consider terminating the pregnancy.

\section{CONCLUSION}

Every individual is exposed to life crises. A pregnancy is a life crisis to a pregnant woman who does not see her way clear to going through with a pregnancy or to educating the child. The feelings and behavioural patterns of the pregnant woman who requests an abortion correspond with those of an individual in any crisis. The woman with an unwanted pregnancy must not be ignored and social work aid should be available when and if she needs it.

Although pre-abortion counselling for the pregnant woman who requests abortion is not compulsory, legislation makes provision for this. In order to do effective pre-abortion counselling and to focus on rendering a social work service of high quality, it is essential to obtain knowledge about the environment that the pregnant woman who requests abortion lives in. A literature study and an empirical investigation succeeded in compiling a profile of such a woman, investigating her behavioural patterns and feelings, and determining what reasons are given for the termination of pregnancy. Adolescence and teenage pregnancy were addressed in this article too, but differentiated from one another, seeing that the adolescent development phase in itself is a crisis period.

\section{REFERENCES}

ANON. 1997. Counselling - a critical part of quality care services delivery of TOP services in the Free State. Reproductive Health Alliance Barometer, 1(2):17-18.

ANON. 2000. Psychological responses to TOP. Reproductive Health Alliance Barometer, (6):42-43.

BABBIE, E. 2004. The practice of social research $\left(10^{\text {th }}\right.$ ed $)$. Belmont: Wadsworth/Thompson. BLOOM, M., FISCHER, J. \& ORME, J.G. 1999. Evaluating practice: guidelines for the accountable professional. Englewood Cliffs: Prentice-Hall.

BRITZ, J.J. 1997. Opvoedkundige sielkundige ondersteuning aan adolessente wat aborsies ondergaan het. [Educational psychologist's support to adolescents who had abortion.] Johannesburg: Rand Afrikaans University (MEd Dissertation)

CAIN, L.P. 1979. Social worker's role in teenage abortions. Social Work, 24(1):52.

CRESWELL, J.W. 2003. Research design: qualitative, quantitative and mixed method approaches $\left(2^{\text {nd }}\right.$ ed). Thousand Oaks: Sage Publications.

DE VOS, A.S., STRYDOM, H., FOUCHÉ, C.B. \& DELPORT, C.S.L. 2002. Research at grass roots - for the social sciences and human service professions. Pretoria: Van Schaik Publishers.

DONDASHE, V.1. 2001. The experience of registered nurses in the pre-counseling of pregnant women contemplating termination of pregnancy. Port Elizabeth: University of Port Elizabeth. (MCur Mini-treatise) 
EVANGELISTI, L. 2000. Adolescent resolution with special reference to pre-abortion counseling. Stellenbosch: University of Stellenbosch. (MA Thesis)

FORREST, G.M. 1994. Emotional distress in women before and after therapeutic terminations of pregnancy. An investigation into the need for pre- and post-abortion counseling. Cape Town: University of Cape Town. (MSc Dissertation)

FOURIE, E. 2004a. Aborsie kan vir jare by vrou bly spook. [Abortion can be a problem to women for many years.] Die Volksblad: 11, 20 May.

FOURIE, E. 2004b. Lig swanger meisies goed in - berader. [Pregnant girls should be informed thoroughly - counsellor.] Die Volksblad: 11, 20 May.

GAMEAU, B. 1993. Termination of pregnancy: Development of a high-risk screening and counseling program. Social Work in Health Care, 18(3/4):179-191.

GELDENHUYS, J. \& DE LANGE, N. 2001. Swart Oos-Kaapse adolessente se ervaring van swangerskapterminasie. [Black Eastern Cape adolescents' experience of the termination of pregnancy.] South African Journal of Education, 21(2):92-98.

HENWICK, A.F. 2001. Locus of control and social variables as they relate to depression at abortion. Johannesburg: Rand Afrikaans University. (MA Dissertation)

HOWES, F. \& GREEN, S. 1997. Buite-egtelike moederskap in die Paarl-Wellingtongebied: die tienermoeder se versorgingspotensiaal en steunstelsel. Pretoria: Raad vir Geesteswetenskaplike Navorsing.

KAUFMAN, K. 1997. The abortion resource handbook. New York: Simon \& Schuster Inc.

LE ROUX, J.P. \& BOTHA, D. 1997. Aborsieberading deur die maatskaplike werker vir swanger tienderjariges en ouer vroue. [Abortion counselling by the social worker for pregnant teenagers and older women.] Die Maatskaplikewerk-Navorser-Praktisyn/The Social Work Practitioner-Researcher, 10(2):169-188.

LE ROUX, J.P. 1995. Aborsie in Suid-Afrika: 'n maatskaplikewerk-perspektief. [Abortion in South Africa - a social work perspective.] Bloemfontein: UOVS. (PhD Thesis)

McCULLOCH, U.R. 1996. Women's experiences of abortion in South Africa: an exploratory study. Cape Town: University of Cape Town. (MA Dissertation)

MOGANO, M.S. 1999. Factors influencing the decision of teenagers to terminate their pregnancies. Johannesburg: Rand Afrikaans University. (MSocSc (SW) Mini-dissertation)

MOJAPELO-BATKA, E.M. 2000. Voluntary termination of pregnancy: meanings and coping with emotional impact of perceived or anticipated social sanctions. Hammanskraal: Medunsa. (MSc Dissertation)

NEUMAN, W.L. 2000. Social research methods: qualitative and quantitative approaches $\left(4^{\text {th }}\right.$ ed). Boston: Allyn and Bacon.

PARRY, G. 1990. Coping with crises. Great Britain, Exeter: PBS Books.

PERSPEKTIEFOPLEIDING [PERSPECTIVE EDUCATION]. 2004. Selfpersepsieskaal (SPS2) [Self perception scale]. Feb, 21.

POLK-WALKER, G.C. 1993. Counseling implications in a client's choice of anaesthesia during a first or repeat abortion. Nursing Forum, 28(1):22. 
REISSER, P.C. \& REISSER, T.K. 1992. Responding to a woman with a crisis pregnancy. Colorado Springs: Focus on the family.

ROYSE, D. 2004. Research methods in social work ( $4^{\text {th }}$ ed). Canada: Thomson Brooks/Cole. RUBEN, A. \& BABBIE, E. 1997. Research methods for social work. Pacific Grove. Calif: Brooks/Cole Publishing.

RULASHE, L. 1999. The psycho-social dimensions of abortion amongst Xhosa speaking women. Port Elizabeth: University of Port Elizabeth. (MA Dissertation)

SA see SOUTH AFRICA.

SAS INSTITUTE. 1999. SAS Institute Inc., SAS OnlineDocR, Version 8, Cary, NC.

SEKUDU, J. 2001. Abortion: a social work study. Pretoria: University of Pretoria. (DPhil Thesis)

STRYDOM, H. 1999. Maatskaplikewerk-navorsing [Social work research]. Potchefstroom: PU for CHE.

SOUTH AFRICA (SA). 1996. Choice on Termination of Pregnancy Act. No 92 of 1996. Pretoria: Government Printer.

TAYLOR, G.L. 1997. Women's experience of abortion - a qualitative study. East London: Rhodes University. (MSocSc Thesis (SW))

VAN DER BERG, R. 1997. Called to care: a Christian counselling perspective on abortion. Sinoville: Group 7 Printers \& Publishers.

ZIMMERMAN, M. 1997. Should I keep my baby? Minnesota: Bethany House Publishers.

Prof Herman Strydom, Subject Group: School of Psycho-Social Behavioural Sciences, Potchefstroom Campus, North-West University, South Africa; Ms Susan Humpel, Chief social worker and Head of the Social Work Department, Potchefstroom Hospital Health Department, North West Province, South Africa. 